Article

\title{
Episodic Retail Settings: A Sustainable and Adaptive Strategy for City Centre Stores
}

\author{
Malin Sundström ${ }^{1, * \mathbb{C}}$, Christine Lundberg ${ }^{2}$ and $^{\mathbb{C}}$ Vassilios Ziakas ${ }^{3} \mathbb{C}$ \\ 1 Department of Urban Studies, Malmö University, 21119 Malmö, Sweden \\ 2 The Norwegian School of Hotel Management, University of Stavanger, 4021 Stavanger, Norway; \\ christine.lundberg@uis.no \\ 3 Independent Researcher, Leeds LS10 1 GB, UK; v_ziakas@yahoo.co.uk \\ * Correspondence: malin.u.sundstrom@mau.se; Tel.: +46-(0)-406-658-648
}

Citation: Sundström, M.; Lundberg, C.; Ziakas, V. Episodic Retail Settings: A Sustainable and Adaptive Strategy for City Centre Stores. Sustainability 2021, 13, 2482. https://doi.org/ $10.3390 /$ su13052482

Academic Editor: Gary Warnaby

Received: 3 February 2021

Accepted: 20 February 2021

Published: 25 February 2021

Publisher's Note: MDPI stays neutral with regard to jurisdictional claims in published maps and institutional affiliations.

Copyright: (c) 2021 by the authors. Licensee MDPI, Basel, Switzerland. This article is an open access article distributed under the terms and conditions of the Creative Commons Attribution (CC BY) license (https:/ / creativecommons.org/licenses/by/ $4.0 /)$.

\begin{abstract}
The fact that an already damaged retail industry is being challenged by a pandemic makes the industry's survival a matter of urban resilience. Sustainable and adaptive strategies are needed to reverse the negative development of the retail sector, and in this conceptual paper, a new perspective is suggested based on episodic retail settings. Such a perspective can increase a physical store's attraction and may serve as a flexible operation strategy for urban retailers and give added value to urban consumers as they shape an ongoing dramatological discourse and facilitate social interaction in a way that traditional fixed-store formats are unable to compete with. By applying the scientific circle of enquiry (SCE), the authors develop an interdisciplinary perspective cutting across the sustainability, service science, and urban studies fields. On this ground, they present a set of conceptual premises and a tripartite conceptual framework delineating how to effectively design episodic retail settings that are adaptive and sustainable. The paper concludes with suggestions for research questions to further advance this field of study.
\end{abstract}

Keywords: retail; sustainability; servicescape design; dramaturgy; sociality; co-creation; urban resilience

\section{Introduction}

Retailing is sometimes seen as the dark side of sustainability, as it promotes consumption. However, retail stores are also identified as important organisational layers to a sustainable society [1]. For example, local retail contributes positively to society in many ways, such as providing services easily reachable to most citizens [2] and thus is an important part of the city's economic structure and sociocultural physiognomy [3]. This is especially true in regenerated areas, where shops and cafés often are important meeting places [4]. Retailing is a pillar in urban sustainability and is fundamental for a city's attraction [5]. When bricks-and-mortar stores close or move to out-of-town centres, restaurants tend to follow, together with office spaces; public spaces disappear and households with less income and no car have less opportunity to drive to alternative locations [6]. In the turbulent environment of accelerated and extremely disruptive change from impacts of technology, digital connectivity, and online shopping, the consequences of high streets (i.e., urban shopping centres) closing down their bricks-and-mortar stores affect city attractiveness [7]. Such a degeneration of retail in city centres had only just begun when the world was struck by COVID-19 and lockdowns, further challenging the already challenged local stores. Now it is clear that we are in the midst of a retail restructuring where city centred retail stores might not survive, and there are strong reasons to believe that old norms and modus operandi of retailing will not return. The extent to which shopping behaviours have been changed by lockdowns caused by the pandemic have provided us with online shopping referrals and out-of-town based shopping. Such a change has implications for the viability of urban resilience and sustainability, expressed in the ideas of 
Barata-Salgueiro and Guimaraes [5] that argue that the urban retail system, urban resilience, city sustainability, and public policies are all closely interlinked.

A sharp decline of fixed-store settings in town and city centre locations may seriously damage and undermine possibilities to promote a vital and sustainable city centre. Solutions and innovations to stop this adverse trend and support a vibrant and sustainable city life are necessary by the urban retail system and public policy makers and must be tailored to local contexts and opportunities. With the advent of COVID-19, rules of social distancing, lockdowns, and the resulting deteriorated retail industry, new perspectives are needed on regenerating high street retail spaces and preventing devaluation or misuse of properties.

In this conceptual paper, we provide an alternative strategic approach to how high street stores can adopt a more sustainable and adaptive strategy to the changing environment within city centres, based on flexible temporary retail settings. A definition of such settings has been introduced by Lugosi, Robinson, Walters and Donaghy [8] (p. 3): "the temporary occupation of spaces for value-creating practices (where) value can take more immediate experiential, affective forms, for example, creating feelings of joy or excitement". In modern times, temporary retail settings are known as pop-ups, often exclusive and branded to improve the level of engagement with consumers [9] and marketed by wordof-mouth promotion [10]. They are often located in high-traffic urban areas, where they are used to expand retailing operations [11,12], and the store itself is often described as the product $[9,13]$.

Motivated by the community idea of the urban city centre [14] and inspired by the fields of literature and on-screen productions [15], we suggest that city centred stores should be viewed as "episodic" [16,17], designed for a specific time and space that can be repeated and re-enacted in separate episodes or instalments, thus making them resilient and adaptive to change. It is therefore here argued that the perspective of "episodic retail settings" makes an important contribution to reshaping a more sustainable urban retail sector, as well as advancing the theoretical underpinnings of the retail and service design research. In this paper, we elaborate on these transitory and short-term retail spaces, drawing upon cultural theory and event dramaturgy [18-21], as they are conducive to triggering a dialogue with consumers through projecting symbolic representations and shared meanings that respond to their needs and concerns. This, if appropriately designed, may serve as a flexible operation strategy for urban retailers and give added value to urban consumers as they shape an ongoing dramatological discourse and facilitate social interaction in a way that the traditional retail spaces are unable to compete with. Accordingly, the design of episodic retail settings is tasked with the mandate to enable collaborative consumption and value co-creation by delivering impactful experiences to customers in a series of instalments [8]. Furthermore, since it is set in a specific time and space, the episodic retail setting is more adaptive to a turbulent environment and more economically sustainable, as these settings are resilient, easy to close down and open up, and are able to create excitement and momentum for the retailing sector, its urban customers, and the urban city centres. Nonetheless, to date, there is a dearth of theoretical work and verification explaining the nature and role of episodic retail settings, as well as how to design such settings. The underlying purpose of the paper is thusly to build an integrative framework for designing episodic retail settings and to advance scholarship on the sustainability of retail service strategy and its intersection with urban studies by offering an interdisciplinary research agenda. This is carried out by integrating pertinent middle-range theories and stipulating a set of configurational premises. Ultimately, the proposed framework can provide the service sector and urban city planners with a heuristic device on how to develop and effectively design sustainable and flexible retail settings.

The outline of this paper is as follows, first materials and methods introducing the scientific circle of enquiry (SCE) are presented, including the general theory and middlerange theories. This is followed by case exemplars, contextual descriptions, and empirical 
generalisations. Next, a discussion of the integrative research framework for designing episodic retail settings is introduced, and, finally, a future research agenda is proposed.

\section{Materials and Methods}

This paper proposes an interdisciplinary conceptual framework cutting across the sustainability, service science, and urban studies fields and specifically focusing on the area of episodic retail settings by applying the scientific circle of enquiry (SCE). The SCE demonstrates a bridge between empirical cases, middle-range theories, and general theory and as such provides methodological scaffolding that connects theory formulation and verification. The rationale is that general theories are too broad and abstract to easily be linked to empirical research, but the middle range theories act as bridge to connect them [22]. Based upon this methodological platform bridging general theory, case exemplars, and middle-range theories, we present a set of conceptual premises and introduce a framework for designing sustainable episodic retail settings, followed by research questions to further advance this field of study.

Following in the footsteps of Kolyperas, Maglaras, and Sparks' [23] work on value cocreation applying the SCE, we introduce a number of exemplars as contextual descriptions of episodic retail settings, informing subsequent configurational premises in order to shape and verify middle-range theories within the retail context. Using the case exemplar methodology, the authors deliberately select entities that illustrate and exemplify the construct of interest that exhibits particular characteristics [24] often used when studying developmental constructs [25] (see Figure 1). Exemplar case study methods are also used when wanting to further advance understanding within the boundaries of a case [26,27], and as such, are deemed as an appropriate method.

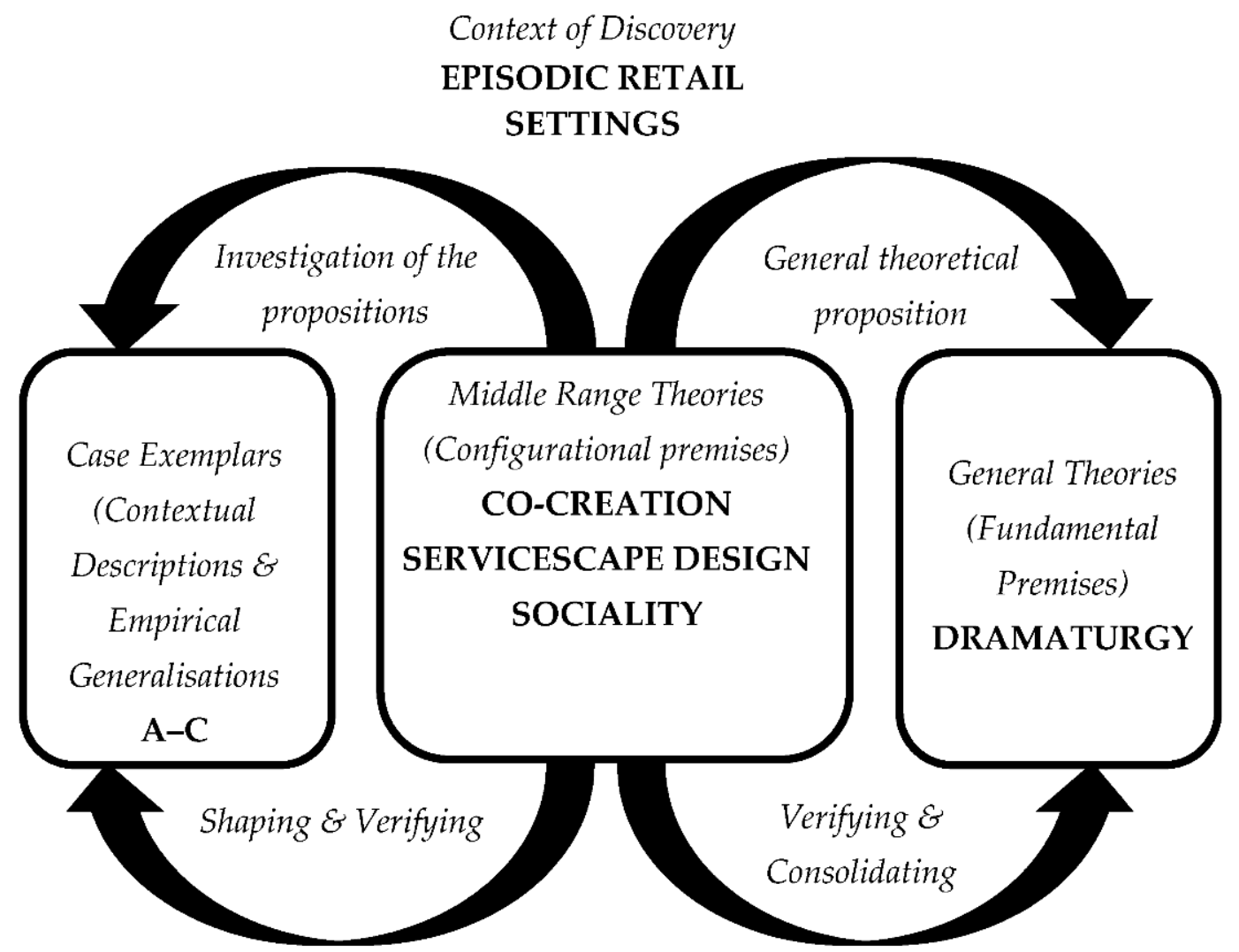

Figure 1. Methodological platform of episodic retail setting design developed in accordance with the scientific circle of enquiry (SCE). 
Three case exemplars within the field of retailing $(A-C)$ are presented, each selected as they exhibit intensive characteristics, clarifying the context of discovery and proposed middle-range theories. Selection criteria included international scope, intensity of episodic retail characteristics, innovation, and differentiation. This ensured that the case exemplars represent an international sample, with each company being engaged intentionally or unintentionally in innovative retail practices, which deviate from each other and "standard" practice. Thus, these case exemplars are deliberately selected to enhance an understanding and contributing to theory as well as to introduce research questions to further the field of study. The exemplars illustrate episodic retail settings designed for a specific time and space and are based on real business cases to showcase the general and middle-range theories.

The logic guiding the development of the framework, inspired by Brodie, Saren, and Pels' [22] SCE approach, is to construct a parsimonious integrative framework that reflects the complex nature of the research problematics, exemplified by the dynamic character and multiplicity of interaction effects that the key theories have in the process.

\section{Episodic Retail Settings and Fundamental Premises from Dramaturgy}

The term episodic structure is often used when it is important to tie concrete circumstances such as time, space, situation, and events into episodes, as it enrichens the narrative [28]. Dramaturgy is almost always based on episodic structures and entails the extraction of shared meanings enabled by the projection and/or performance of symbolic representations [21]. This perspective employs Goffman's [29] theatrical paradigm of dramaturgy to explain social action and behaviour. Goffman contended that the nature of social life is inherently dramatic and that people in all their social interactions play particular roles and reproduce performative conventions through the rehearsal of and familiarity with social scripts. Turner $[18,19]$ extended Goffman's notion of dramaturgy to theorise public performances as collective forms of rituals and social dramas conveying a multiplicity of meanings expressing the human need to construct and interpret the conditions that constitute their lives. Dramaturgy is a mode of symbolic action [29] in that its enactment takes place through a kind of performance that exemplifies expressive and dramatic dimensions [30]. Thus, it can be said that the interplay of performance and dramaturgy shapes a symbolic context in which people express their understanding of the social world. Likewise, staging and designing episodic retail settings can be understood as a space invoking cultural significations that, through their dramaturgical narratives and symbols, facilitate emotional attachment and interpretation of a retailer brand by consumers. From a dramatological perspective, the staging and design of episodic retail settings can therefore be analysed as a text conveying messages that project and/or explain the qualities of a retailer brand and its attractive characteristics to consumers as well as urban city centres. In this regard, signs tied to space and brands may reinforce intended meanings via the strategic use of polysemic structures such as symbols, narratives, and genres (music, rituals, games, etc.).

Dramaturgy has not been systematically examined in the context of episodic consumption, with few examples in different contexts [31-34]. According to Grove and Fisk [31], the service experience as theatre framework captures many of the episodic dimensions of a retail setting. From the marketer's perspective, attention to the dramaturgical dimensions of a service exchange may enable the marketer to deliver consistently higher levels of consumer satisfaction. However, existent marketing applications do not synthesise dramaturgy with performance studies to reveal the meanings of symbolic representations enacted through collective expressive practices. Such a dramatological synthesis focusing on the performance of co-creative practices and shared meanings moves beyond the predominant focus of consumer culture theory on individuals per se.

A dramatological perspective can also shed light on the social construction process of the staging and design of episodic retail settings and its identity as, by employing the metaphors of performance and performativity [21], such venues can be analysed as a 
series of performances within spaces that are continuously created by the performances of staff and consumers. As such, the making of an episodic retail setting experience is the outcome of projected signs and their interactions with city stakeholders emanating from the contextual environment of space (human, social, cultural, physical, etc.). Hence, an orchestrated use of such venue signs tied to social or existential issues can foster cultural performance manifestations that invigorate and (re)create the symbolic meanings that instantiate the values of retailer brands by enabling metaphoric discourse between consumers, staff, and the urban space. This collective performance for extracting shared meaning brings to the fore the intersection between dramaturgy, value co-creation, sociality, and design of physical setting that is being moulded within the sharing economy.

\subsection{Case Exemplars: Contextual Descriptions and Empirical Generalisations}

A. GLOSSIER AND CO-CREATION (Figure 2). This online cosmetics company (mainly targeting Millennials and Gen-Zs) invites their loyal customers and influencers to visit their Instagram-friendly physical pop-up experience in Los Angeles. The customers are greeted by employees dressed in pink jumpsuits (company brand colour), thus constituting a bridge between the brand and employee encounter. The space is bright and designed as an interactive art gallery where visitors are instructed to touch and feel and to co-create with friends "IRL" (i.e., "in real life") and on social media. Customers can view and test the products, and at different points in the store, customers are encouraged to share their experiences with friends and by taking selfies. This is aptly named "taking a shelfie", following the logic of selfies, as customers are taking selfies in front of the product shelf. The customers are also encouraged to enter the selfie canyon designed in the company colours, which has its own hashtag. It is an immersive, custom-designed room inspired by a local canyon, with day-to-night lighting and real-life desert sounds. The purpose of the design is for customers to share their experiences on social media and be a part of the lived experience and episodic retail setting with other customers.

B. SHOWFIELDS LAB AND SERVICESCAPE DESIGN (Figure 3). With the aim of bringing lesser-known brands with a sustainable core to the market, this actor offers episodic installations in the form of short sensory theatre productions. The retail setting is designed to give customers a chance to immerse themselves in different featured brands using strong colours, concrete-coloured flooring, and art installations, interspersed with traditional wall-hung artworks. They decorate each room in line with the respective brand expression. Technological installations offer customers further enhancement of product experiences and each product can also "talk" to the customer with the help of a mobile application. This provides the customer with an opportunity to find out more about manufacturing, design, shipping, and function. The dramaturgical features of the design allow the visitor to have an immersive theatrical experience in an environment reminiscent of an escape room but at the same time offering opportunities to share the experience with others via social media.

C. LEGO AND SOCIALITY (Figure 4). This company operates on the toy market offering a well-known product built on the construction idea and with a mission to inspire and develop builders of tomorrow. With the aim of bringing people together and play, the company focuses their episodic retail setting on playfulness and inspiration. Their pop-ups are built to offer the best possible space for play, and visitors are encouraged to interact with other visitors. These interactions are inspired by different challenges and by employees taking an active role as advisors and guides. The product and its episodic retail settings allow a symbolic-sign-perspective for fellowship and foster sociality and new narratives. The retail settings are operated the same way as their media channels, using measurements such as "likes" and "shares". The narratives and customer surveys focus on social aspects of visitor experiences, such as on how they played, what they learnt, and how they felt. 
These exemplars all have a scope that could be explained through a dramatological lens. Layered symbols throughout the retail settings and multiple narratives are used to convey shared meaning by engaging staff and customers in embodied performances that continue an ongoing dialogue with the episodic setting and the destination. This metaphoric discourse elicits affective responses by consumers about the value of such settings. The retail industry and designers of episodic retail settings can facilitate the development of emotional links between consumers through setting design, as illustrated in the exemplars above. For example, the setting can act as primary motivation for visits as well as incorporating features of this link in the designed physical environment of such venues. Retailers could also apply these perspectives by promoting their employees as being part of the mythology of the setting and staging them as actors. Additionally, the mythology of the environment, created through, for example, storytelling narratives, needs to be deliberately designed into the episodic retail setting. This was, for example, explored in de Lassus and Freire's [35] netnographic study of pop-up luxury stores and how they reinforce the mythical semiotic significance of luxury brands. However, the exemplars also have a scope that could be explained with intermediary bodies of theory, here referred to as middle-range theory. Such theoretical perspectives are employed to formulate a set of premises for the optimal design of episodic retail settings. These premises are coined "configurational" to highlight the focus on arranging different design elements in a combinational form that optimises the impact of episodic retail settings on consumers and destinations.

\subsection{Episodic Retail Setting Design and Configurational Premises}

The common characteristics of episodic retail settings in the exemplars that are presented in Figures 2-4 are the collaborative patterns in consumption and production that epitomise conduits for co-creation enacted through consumption cultures. This phenomenon has been described as consumers' creation of value, and it is showcased in customer-tocustomer activities in cases like Ludic and Wikipedia [36-39]. The reasons that lie behind such consumer behaviour have been documented as altruistic desires to contribute to something beyond the self, construct identity, engage in self-expression, be recognised by peers, earn social capital, and develop personal relationships [39].

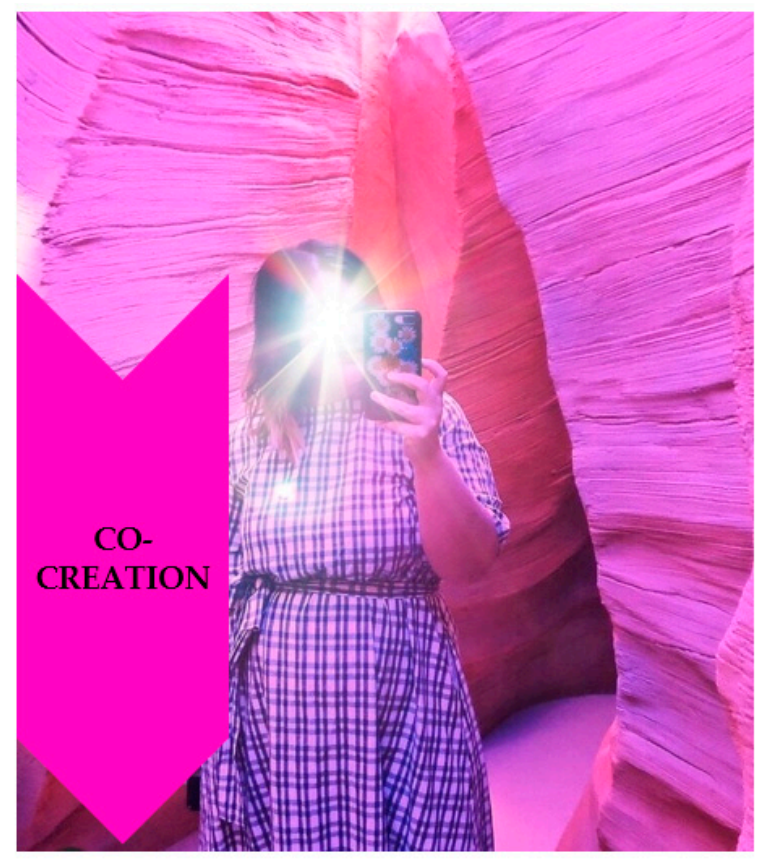

Figure 2. The Glossier's canyon and co-creation as the intermediary body of theory (photo credit: @christinawinkelmann on Instagram). 
Part of co-creation in pop-up settings is peer surveillance and socialised performances which according to Lugosi, Robinson, Walters and Donaghy [8] help shape consumer behaviours, expectations, and interpretations, which suggests strong communities/social networks. This active participation in co-creation is typical of the postmodern era. In some cases, such invested consumers view their relationship with the object of interest as an extension of self and a large part of their identity. The extension of self is defined as a release from everyday life, expressing a person's pleasure, narcissism, emancipation, and empowerment [40-42]. Within marketing and retail literature, it is most common to connect invested customers with brand image, brand affect, and brand loyalty [43]; however, that connection almost never understood them in terms of "till death do us apart" monogamy [44], city attractiveness, and sustainability. Still, there are some examples of retailing actors managing to display intense monogamous behavioural loyalty, proving supernatural, religious, and almost magical motives-for example, in the case of Apple [45].

To better understand and examine the strategic design of episodic retail settings, it is therefore suggested that the intermediary body of theory based on case A is co-creation.

Based on the proposed middle-range theory co-creation and case exemplar $\mathrm{A}$, the following configurational premise is recommended:

Configurational premise 1: The design of episodic retail settings requires that consumer involvement and emotional ties be driven by collaborative productivity.

The staging of physical settings, with its origin in environment psychology, is often referred to as a servicescape, a term coined by Bitner [46]. Servicescape design is defined as the "design [of] buying environments to produce specific emotional effects in the buyer that enhance his [or her] purchase probability" [47] (p. 50). Some of the early research on servicescapes was based on retail environments, identifying retail atmospherics (e.g., proximity, lighting, colour), aural (e.g., noise, music), tactile (e.g., cleanliness), and olfactory (i.e., scent) cues as central for customers' perceptions and behaviour [47]. Bitner [46] later developed the concept by introducing her framework of ambient cues [47] (e.g., atmospherics, aural, and olfactory cues), space/function (e.g., spatial layout and function), and signs, symbols, and artefacts (e.g., signage and décor). Baker [48] developed the framework further by introducing social factors that were further divided into social macro- (e.g., culture and social class) vs. micro-environment (interaction and psychology) by, for example, Peter, Olson, and Grunert [49]. A substantial number of studies have been published on these social factors, focusing on staff and customer as well as customer-to-customer interactions [50-55]. A significant amount of research within the field has focused on the ambient cues of a setting, such as music [56,57], temperature [58], scent/odour [56,59], lighting $[60,61]$, and cleanliness $[62,63]$. Layout and its functionality have also received an impressive amount of attention by researchers [64], linked to store brand design and time spent in store [65]. Design factors such as use of materials, architecture, scale, and décor are all perceived to have an impact on consumers' perceptions of the setting and their cognitive and emotional responses (e.g., comfort or discomfort) to it [66-69]. All these ambient and physical cues of a physical setting play an important part, on a conscious and subconscious level, in the image formation of a brand, company, product, and service [70,71]. An additional contribution to the servicescape framework was the introduction of substantive and communicative staging [72,73]. The former is about the adaptation of the physical environment and the latter about how the meaning of servicescapes is communicated and interpreted. Central to staging is to evoke narrative themes based on shared cultural symbols and ambient cues [72]. Closely linked to staging is the commoditisation of the physical environment [74] and hyperrealism, i.e., the intersection between reality and the simulated [75].

Technology development has created many opportunities for immersive staging of retail environments. It is not only the different new forms of purchasing linked to digital development and virtual reality/augmented reality, i.e., online consumption [76] but also the design of the physical environment and creation of communicative staging in the retail setting. Despite the opportunity that technology provides, fixed store settings do not capi- 
talise on the possibilities of, for example, virtual reality tools in the creation of augmented realities in retail, which would help foster consumer identifications and experiential retail settings. Examples of how such ideas could be implemented in experiential retail settings are the use of holograms, virtual hostess technology, radio frequency identification (RFID), and smart mirrors. The use of technology where customers sign in upon arrival and the system recognises the customers' needs and history can also be useful in such settings. However, to create such augmented realities, one does not always require investment in new technology. Traditional methods in the design of experiences such as fashion shows or the use of food and beverage - tools that engage all human senses—can be implemented to create experiential retail settings. The main purpose of all these tools is to communicate and enforce the sense of immersion for customers and to build the story of the brand, product, company, staff, or customer.

Technology has also been used in experiential environment design to create hyperrealism. The concepts of hyperrealism and simulacra were first introduced by Baudrillard [75], describing the intersection between "reality" and the simulated. In this dimension, the "real" is dissolved, and simulated codes (substitutes for reality) are transferred through media and consumption. In a tourism or retail setting, it is partly manifested using technology, such as an app, where the perception of reality and fiction are blurred owing to the use of the tool. This elevates polysemy, allowing consumers to make their own interpretations of what is real or is not. Polysemic structures using symbols and narratives can be designed and orchestrated to guide consumers through their readings.

To better understand and examine the strategic development of episodic retail settings, it is thus suggested that the intermediary body of theory regarding exemplar B is servicescape design through storytelling.

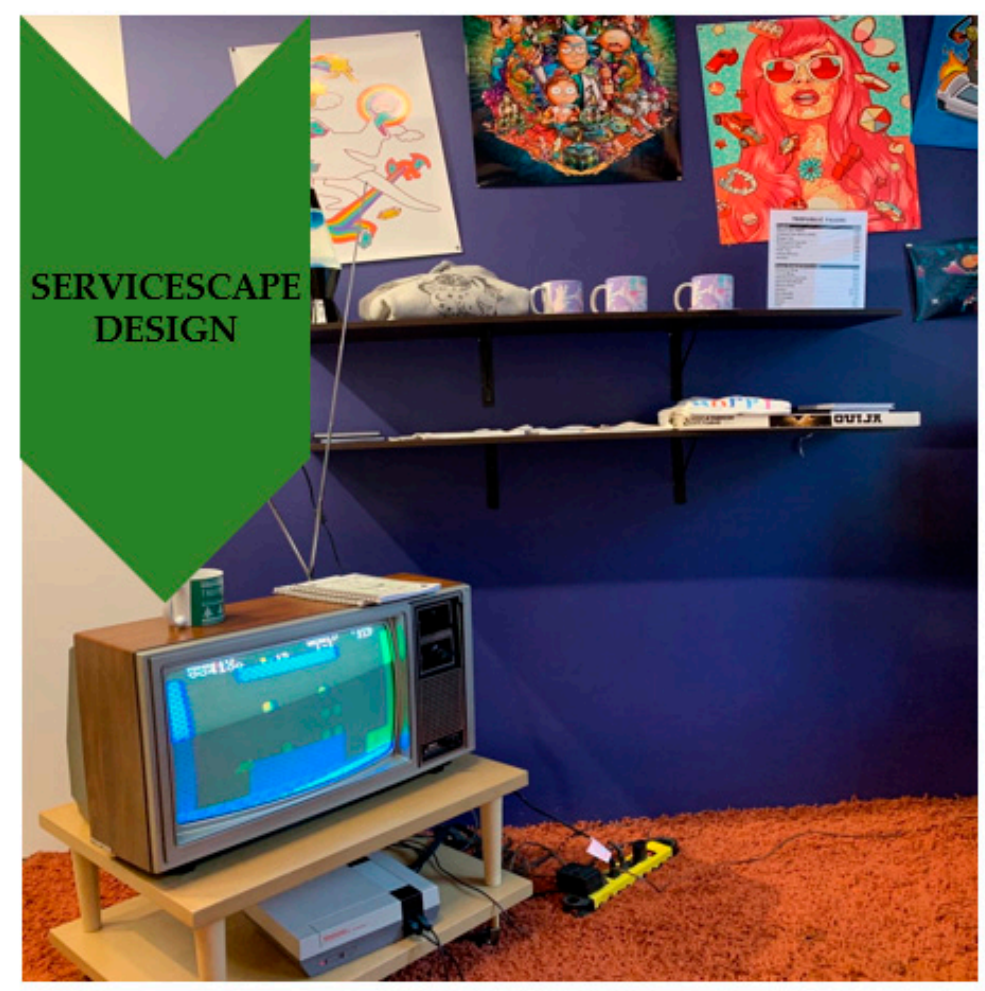

Figure 3. Showfields Lab and servicescape design as the intermediary body of theory (photo credit: Sofia Norén). 
Based on the recommended middle-range theory, servicescape design through storytelling and exemplar $\mathrm{B}$, the second configurational premise proposed is:

Configurational premise 2: The design of episodic retail settings is based on the intentional design of the physical environment and storytelling conducive to the reinforcement of polysemic structures.

The pivotal role of front-line employees' performances in service encounters with customers and their "boundary spanning" role has been under study in numerous studies [77-80]. This interaction between staff and customer, also referred to as the service encounter or "moment of truth" [81], is one of the most well researched topics in the services marketing management field [82,83]. An often-employed definition of the service encounter which emphasises both the social interaction and the physical environment's importance for customer experiences is: "discrete, separate, and distinct events and behaviour, as well as a customer's interaction with all the dimensions of a service, such as the physical surroundings and the service contact employees" [84], (p. 249). Several different perspectives have been employed when exploring the service encounter. The first is the customer perspective in which attention has been given to the link between service encounters and purchase intentions [85], perception of service quality [86-89], service failure, and recovery [90-92]. A complementary approach on service encounters employed in previous research is the employee perspective. Central in this research has been the perception of trust in service encounters [93] and the delivery of service quality [94]. A dyadic approach combining these two perspectives has also been published, focusing the emotional contagion, also linked to emotional labour [95,96].

Employee skills demonstrated in service encounters such as these have been categorised into three different groups: "hard" skills, "soft" skills, and aesthetic skills. Hard skills are skills that relate to the technical execution of a job. In retail, this would be knowing the product range and managing the check-out desk. When it comes to the design of episodic retail settings, a useful hard skill would be employees' storytelling abilities that would prove useful in the creation of an augmented service encounter reality. In their study, Lundberg, Lexhagen, and Mattsson [97] emphasised the importance of employee storytelling skills in physical environments with few physical cues, creating immersive experiences. Their conclusion was that the lower the level of physical cues in the environment, the higher the demand for a high level of social cues (e.g., employees' storytelling abilities). Soft skills, on the other hand, are skills composed by attitudinal and behavioural aspects of the job in interactions with customers (and co-workers). Skills like courteousness, understanding, and responsiveness [98] are central soft skills in service encounters. The term emotional labour has been used to describe these skills $[99,100]$. In more recent studies, the sometimes-controversial skill set—aesthetic skills—has been introduced, incorporating appearance and verbal communication. It comprises an employees' ability to "look and sound good/right" for the role [52]. An episodic retail setting puts demands on strategy to develop new staff skills. In a traditional store environment, the focus is primarily on securing staff's technical skills, such as managing a register and knowing the product range. In addition to these skills, some retail environments emphasise the need for social skills in the recruitment of new staff and professional development of existing staff. However, in an episodic retail setting, where the focus is to create immersive experiences for customers, central skills of staff are aesthetic and social skills (e.g., through emotional labour) -with which the employees are to manifest the company physically, verbally, and socially.

Employees this way become the living embodiment of the company epitomising its core meanings and values. Their signification of meaning can be facilitated by staged role-playing between employees and consumers to give life and enhance the symbolic representation of the store. Staged performances add to the discourse that a brand seeks to keep with consumers, representing its positive attributes. This coincides with a view of sociality as a dynamic relational matrix within which people are constantly interacting in ways that are co-productive, continually plastic and malleable, and through which they come to know the world they live in and find their purpose and meaning within 
it [101]. The matrix encompasses relations with both human and non-human elements (e.g., atmospheric cues and objects). Being episodic, the advantage is that embodied performances can repeatedly prompt attention of consumers with the creative use of different themes and combinations of polysemic structures (symbols and narratives) aimed at constantly updating, re-creating, and re-invigorating the relational matrix of sociality. It is thus critical to design "orchestrated" settings in a manner that they convey a coherent storyline performed in a series of instalments and different combinations of symbolic elements. To optimise the effect of polysemic structures, the orchestration of staged performances and symbolic elements needs to complement and add value to one another, thus creating a synergistic and malleable terrain in which shared meaning can be profitably cultivated.

Lastly, to better understand and examine the strategic design of episodic retail settings, it is herein proposed that the intermediary body of theory related to exemplar $\mathrm{C}$ is sociality.

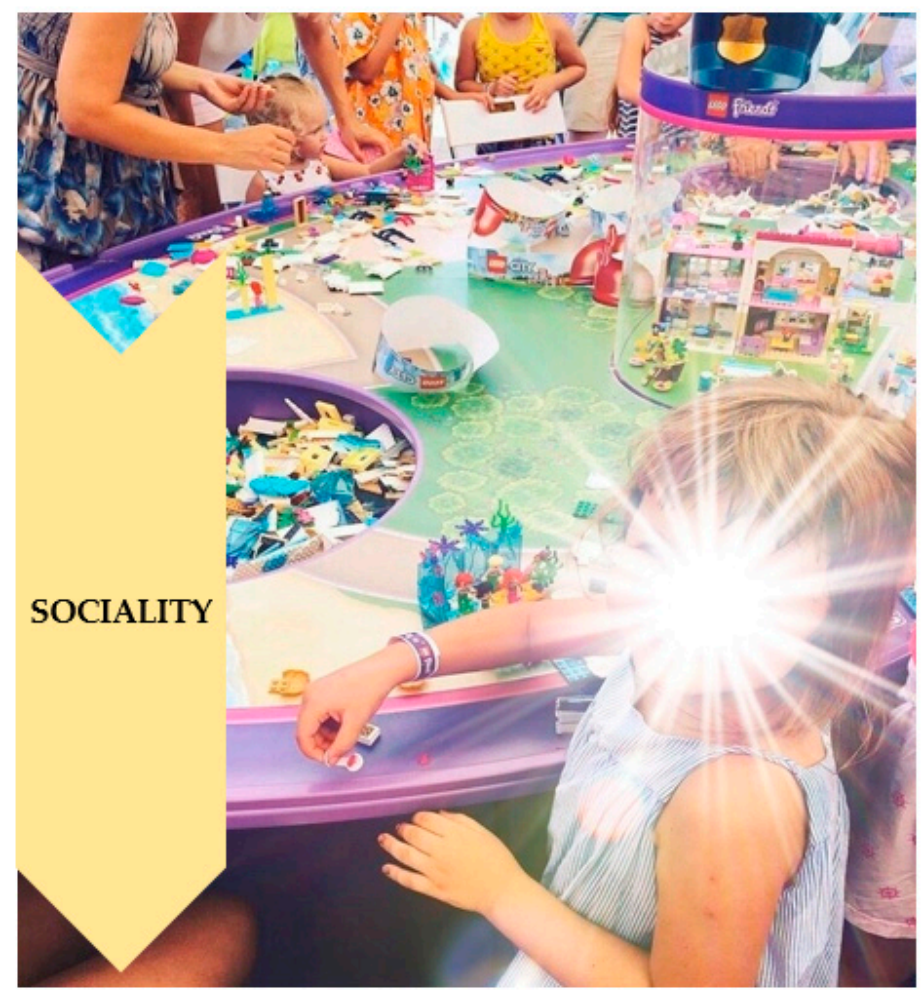

Figure 4. Lego and sociality as the intermediary body of theory (photo credit: @diandra_ya on Instagram).

Based on the recommended middle-range theory sociality and exemplar C, the third and final configurational premise proposed is:

Configurational premise 3: The deliberate design of episodic retail settings is enabled by sociality through collaborative productivity between staff and customers, consumer identifications, and polysemic structures.

Consequently, when advancing the conceptual discourse of episodic retail settings under the prism of dramaturgy, three middle-range theories are in focus-co-creation, servicescape design, and sociality. Central is the synergy of activities that take place between consumer involvement (e.g., collaborative productivity), commodification processes in the design of the commercial environment (e.g., creation of hyperreality elements), staff engagement and facilitation (e.g., use of storytelling) in order to initiate perceptions of consumption authenticity and affective response [8,35]. By identifying and purposefully investigating these important areas and their interconnections, conceptual insights have been made and resulted in the creation of an integrative, contextually driven, and interdisciplinary framework on episodic retail settings. 


\section{Discussion: An Integrative Research Framework for Designing Episodic Retail Settings}

Based on the fundamental tenets from dramaturgy and the above configurational premises, this paper presents a tripartite framework that delineates the critical constituents and their esoteric relations in the process of designing episodic retail settings.

Figure 1 encapsulates the methodological platform used in the theory-building process. This brings forward the synergistic means that shape and galvanise an episodic retail setting enabled by the facilitating tools of consumption, staff engagement, and the design of physical environment. The middle-range theory of co-creation denotes the fundamental role of collaborative productivity between staff and consumers as an antecedent in the design of episodic retail experiences. The significance of social context for episodic retail experiences is highlighted by the concept of sociality as a dynamic matrix that underpins the need to offer opportunities for social interaction with both human actors and nonhuman elements in making meaningful the procedures of co-creation in designed servicescapes. The general theory of dramaturgy epitomises the value of polysemic structures via the use of embedded signs laden with symbolic meaning(s) within episodic retail settings. Thusly, consumers and staff as the actors in co-creating and co-experiencing retail settings should become engaged in hyperreality staging that can foster brand attachments. Accordingly, consumers should be instigated to develop emotional ties with retail settings and brands grounded on meaningful identifications and storytelling that are amplified by polysemic structures and can, in turn, contribute to enhancing their perceptions of consumption authenticity.

The resultant framework of episodic retail setting design is illustrated in Figure 5 based on a tripartite structure and is a heuristic device on how to develop and effectively design strategies that are adaptive and sustainable. In order to truly create episodic retail settings insights on consumer involvement, affective response, engagement and facilitation, physical design, and hyperreality need to be integrated so that the industry can develop this retail interface within a global, digital, and postmodern world. Therefore, the proposed tripartite framework is integrative in nature. Its contribution reflects concepts traditionally not considered within the marketing literature when studying temporary retail settings. It integrates theoretical tenets from the domains of cultural studies, sociology, environmental psychology, and human resource management, as applied within the realm of retail experience design. Specifically, an interdisciplinary approach is proposed here that examines the complex relationship between dramaturgy, sociality, co-creation, design of physical (servicescape) environment and hyperreality, consumer involvement, response, staff engagement and facilitation in episodic retail settings. For example, the co-creation of immersive retail experiences through consumer involvement and staff engagement/facilitation would bring together researchers from marketing, human resource management, and psychology. The rendering of immersive experiences using dramaturgy in social and physical design of the retail setting could also assemble scholars from cultural studies.

The notion of episodic retail settings is to a majority of marketing researchers an unexplored phenomenon, and thus their design is a new art. By drawing upon the theoretical lens of cultural studies and dramaturgy, we add an overlooked interpretive perspective that complements the established insights of marketing and retail scholarship. It does not only bring to the fore analogies of retail settings as sociocultural microcosms, but more importantly, it pinpoints that taking part in and experiencing retail encounters could be seen as a form of interpreting and co-constructing the world around us. This more rounded perspective has the potential to enable the sustainability of retail settings and their embeddedness within their urban ecosystems in terms of their adaptive capacity, longevity of their lifespan, and subsequent contribution to the socioeconomic regeneration of urban centres. In doing so, it can effectively compensate for the decline of fixed store settings in high streets, which undermines the sustainability of a lively city centre. In the post-pandemic period, it is important to support a vibrant and sustainable city life by 
implementing flexible, adaptive retail strategies as a means for enabling public policies to link the urban retail system with urban resilience and city sustainability. Application of this perspective to different local contexts can, in turn, potentially generate further opportunities for reaching sustainability in the retail system of city centres.

\section{EPISODIC RETAIL SETTING EXPERIENCE}

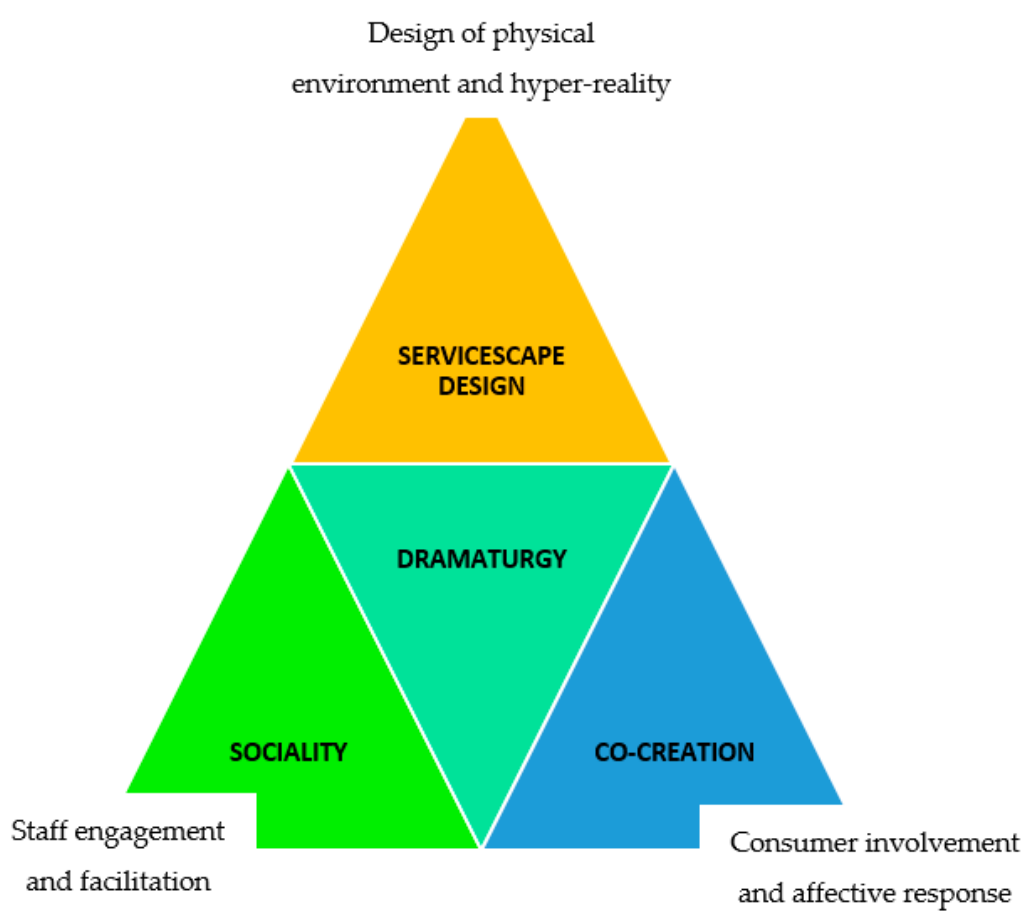

Figure 5. The tripartite model of episodic retail setting experience design.

Considering the theoretical focus in this paper, presenting a tripartite framework of designing episodic retail settings, and suggestions for further research to advance the discourse on this area, less concern has been given to a managerial operations perspective. To avoid the risk that this article only remains a theoretical work, we therefore offer some practical advice for retail managers. The idea of episodic retail settings underlines the need for companies to devote more efforts/resources to staging experiences, that is, to identify themselves as actors not managing products but instead as actors directing, assisting, and creating episodic retail settings whereby a customer can get a heightened shopping experience. Often, the perspective of goods needs to change, suggesting that products should be seen as merely props; the core business is the stage and its performance. Many retailing actors need to develop new perspectives on their business through evocative imagery, used as an idea to adapt business scope and operations, add value, and alter their business model. Additionally, retailers must review their strategies for renting or owning their retail space. Ownership provides benefits such as control over costs but affects the ability to be adaptive and flexible. Rental models provide greater freedom, but unfortunately current leases often mean that rents are high, and contracts are long and far from as flexible as one would like. For that reason, retail players must look for property owners who have a more flexible view of contract time horizons or simply try to find new players who can provide temporary location for episodic retail settings with low rental costs, e.g., in rebuilt containers or similar. This would mean that more players can apply our proposed ideas on episodic retail settings and at the same time improve their margins. 


\section{Conclusions: Towards Building a Future Research Agenda}

It is this paper's aim to advance the discourse for further research on episodic retail settings using the theoretical perspectives of co-creation, servicescape design, sociality, and dramaturgy. This interdisciplinary approach to investigate the proposed theories and related research questions (see Table 1) can result in a re-construction of retail strategy for fixed store settings as well as innovative approaches to sustainability within urban retail and flexibility in terms of potential new lockdowns and/or pandemic events. The approach can also contribute to highlighting dimensions of scalability and replicability, elements supporting the development of temporary retailing activities.

Table 1. Middle-range theories and research questions for sustainable and adaptive episodic retail settings.

\begin{tabular}{|c|c|}
\hline Middle-Range Theories & Research Questions \\
\hline Co-creation & $\begin{array}{l}\text { 1. What conditions facilitate collaborative productivity } \\
\text { between customers and staff? } \\
\text { How does the commodification of signs drive or constrain } \\
\text { 3. How can customer involvement and staff engagement be } \\
\text { best synthesised and optimised? }\end{array}$ \\
\hline Servicescape design & $\begin{array}{l}\text { 1. What factors enable the construction and extraction of } \\
\text { storytelling within episodic retail settings? } \\
\text { 2. How can assigned meanings be used to build a retail brand? } \\
\text { 3. What combination of signs can enable the optimal use of } \\
\text { polysemic structures? }\end{array}$ \\
\hline Sociality & $\begin{array}{l}\text { 1. What are the best means to design opportunities for social } \\
\text { interaction within episodic retail settings? } \\
\text { 2. How can emotional ties for customers be amplified through } \\
\text { 3. Hocial interaction? } \\
\text { interaction? }\end{array}$ \\
\hline
\end{tabular}

The instrumental applicability of the proposed framework is particularly evident in turbulent times of crisis like the COVID-19 pandemic. Given that the retail sector is especially vulnerable in cases of pandemics, most recently COVID-19, it is important to have strategies for how operations can be conducted when peoples' mobility is restricted and in times of social distancing measures. In such cases, the proposed structures for episodic retail settings can play an important role in terms of city attraction, for example, by capitalising on the temporality of episodic installations, taking advantage of the fact that they can be rolled out in a limited space and time, and limiting congestion by virtue of being episodic installations. If it turns out that episodic retail settings will be a formidable success, operations managers must also take into account any risks of the retail settings becoming overcrowded. One way to avoid congestion and queues can be to create add-on values by scheduling the visits, differentiating specific times as premium, and using such adaptive strategies as a means for both control and higher profitability.

This conceptual paper is not without limitations. Firstly, it is important to identify additional factors, parameters, or contexts that may influence the design and strategy of episodic retail settings. While the proposed framework sets a ground for such an inquiry, more thorough investigations in the future may reveal further dynamics, variables, and interaction patterns. Secondly, although the integrative framing of pertinent theories provides a heuristic device for the strategic design of episodic retail settings, there is a need to develop systematic tools for the evaluation of associated processes and measurement of 
outcomes. Thirdly, further refinement and empirical testing of the proposed framework is needed before managers will be able to leverage the expected benefits of designing episodic retail settings.

Author Contributions: Conceptualisations, M.S., V.Z., and C.L.; methodology, M.S., V.Z., and C.L.; validation, M.S., V.Z., and C.L.; formal analysis, M.S., V.Z., and C.L.; resources, M.S., V.Z., and C.L.; writing—original draft preparation, M.S., V.Z., and C.L.; writing—review and editing, M.S., V.Z., and C.L.; visualisation, M.S., V.Z., and C.L. All authors have read and agreed to the published version of the manuscript.

Funding: This research received no external funding.

Institutional Review Board Statement: Not applicable.

Informed Consent Statement: Not applicable.

Data Availability Statement: Not applicable.

Conflicts of Interest: The authors declare no conflict of interest.

\section{References}

1. Wiese, A.; Zielke, S.; Toporowski, W.; Lehner, M. Translating sustainability: The role of the retail store. Int. J. Retail Distrib. Manag. 2015, 43, 386-402. [CrossRef]

2. Balletto, G.; Ladu, M.; Milesi, A.; Borruso, G. A Methodological Approach on Disused Public Properties in the 15-Minute City Perspective. Sustainability 2021, 13, 593. [CrossRef]

3. Bosworth, G.; Rizzo, F.; Marquardt, D.; Strijker, D.; Haartsen, T.; Aagaard Thuesen, A. Identifying social innovations in European local rural development initiatives. Innov. Eur. J. Soc. Sci. Res. 2016, 29, 442-461. [CrossRef]

4. Carley, M.; Kirk, K.; McIntosh, S. Retailing, Sustainability and Neighbourhood Regeneration; Joseph Rowntree Foundation: York, UK, 2001.

5. Barata-Salgueiro, T.; Guimarães, P. Public Policy for Sustainability and Retail Resilience in Lisbon City Center. Sustainability 2020, 12, 9433. [CrossRef]

6. Tach, L.M. More than bricks and mortar: Neighborhood frames, social processes, and the mixed-income redevelopment of a public housing project. City Community 2009, 8, 269-299. [CrossRef]

7. Daunfeldt, S.O.; Mihaescu, O.; Öner, Ö.; Rudholm, N. Retail and place attractiveness: The effects of big-box entry on property values. Geogr. Anal. 2020. [CrossRef]

8. Lugosi, P.; Robinson, R.N.S.; Walters, G.; Donaghy, S. Managing experience co-creation practices: Direct and indirect inducement in pop-up food tourism events. Tour. Manag. Perspect. 2020, 35, 100702. [CrossRef]

9. Lowe, J.; Maggioni, I.; Sands, S. Critical success factors of temporary retail activations: A multi-actor perspective. J. Retail. Consum. Serv. 2018, 40, 74-81. [CrossRef]

10. Klein, J.F.; Falk, T.; Esch, F.-R.; Gloukhovtsev, A. Linking pop-up brand stores to brand experience and word of mouth: The case of luxury retail. J. Bus. Res. 2016, 69, 5761-5767. [CrossRef]

11. Alexander, B.; Nobbs, K.; Varley, R. The growing permanance of pop-up outlets within the international location strategies of fashion retailers. Int. J. Retail Distrib. Manag. 2018, 46, 487-506. [CrossRef]

12. Spitzkat, A.; Fuentes, C. Here today, gone tomorrow: The organization of temporary retailscapes and the creation of frenzy shopping. J. Retail. Consum. Serv. 2019, 49, 198-207. [CrossRef]

13. Surchi, M. The temporary store: A new marketing tool for fashion brands. J. Fash. Mark. Manag. Int. J. 2011, 15, 257-270. [CrossRef]

14. Park, Y.; Wiegerink, K. Smart Resident-Driven City Hospitality: An Explorative Study about How Smart Principles Can Create Long-Term Value for the Communities of the City Centre. In Sustainable Hospitality Management; Ruël, H., Lombarts, A., Eds.; Emerald Publishing Limited: Bingley, UK, 2020. [CrossRef]

15. Lundberg, C.; Ziakas, V.; Morgan, N. Conceptualising on-screen tourism destination development. Tour. Stud. 2018, 18, 83-104. [CrossRef]

16. Kelleter, F. Five Ways of Looking at Popular Seriality. In Media of Serial Narrative; Kelleter, F., Ed.; Ohio State University Press: Columbus, OH, 2017; pp. 7-34.

17. Denson, S.; Mayer, R. Border crossings: Serial figures and the evolution of media. NECSUS. Eur. J. Media Stud. 2018, 7, 65-84.

18. Turner, V. The Ritual Process: Structure and Anti-Structure; Aldine de Gruyter: New York, NY, USA, 1969.

19. Turner, V. Dramas, Fields and Metaphors: Symbolic Action in Human Society; Cornell University Press: Ithaca, NY, USA, 1974.

20. Ziakas, V. Fostering the social utility of events: An integrative framework for the strategic use of events in community development. Curr. Issues Tour. 2016, 19, 1136-1157. [CrossRef]

21. Ziakas, V.; Costa, C.A. The show must go on': Event dramaturgy as consolidation of community. J. Policy Res. Tour. Leis. Events 2012, 4, 28-47. [CrossRef] 
22. Brodie, R.J.; Saren, M.; Pels, J. Theorizing about the Service-Dominant Logic: The bridging role of middle range theory. Mark. Theory 2011, 11, 75-91. [CrossRef]

23. Kolyperas, D.; Maglaras, D.; Sparks, L. Sport Fans' Roles in Value Co-Creation. Eur. Sport Manag. Q. 2019, 19, 201-220. [CrossRef]

24. Bronk, K.C. The exemplar methodology: An approach to studying the leading edge of development. Psychol. Well-Being Theory Res. Pract. 2012, 2. [CrossRef]

25. Bronk, K.C.; King, P.E.; Matsuba, M.K. An introduction to exemplar research: A definition, rationale, and conceptual issues. New Dir. Child Adolesc. Dev. 2013, 142, 1-12. [CrossRef]

26. Mabry, L. Case study in social research. In The SAGE Handbook of Social Research Methods; Alasuutari, P., Bickman, L., Brannen, J., Eds.; SAGE Publications Ltd.: Thousand Oaks, CA, USA, 2012; pp. 214-227.

27. Morgan, P.E. The Effects of Work in an Exemplar Continuously Improving Lean Production System: A Case Study. Ph.D. Thesis, University of Phoenix, Phoenix, AZ, USA, 2018.

28. Mueller, R.A. Episodic narrative interview: Capturing stories of experience with a methods fusion. Int. J. Qual. Methods 2019, 18, 1609406919866044. [CrossRef]

29. Goffman, E. The Presentation of Self in Everyday Life; Anchor Books: New York, NY, USA, 1959.

30. Schechner, R. Performance Theory; Routledge: London, UK, 2003.

31. Grove, S.J.; Fisk, R.P. The service experience as theater. In NA-Advances in Consumer Research, Association for Consumer Research; Sherry, J.F., Sternthal, B., Eds.; Association for Consumer Research: Provo, UT, USA, 1992; pp. 455-461.

32. Halliday, S.V.; Davies, B.J.; Ward, P.; Lim, M. A dramaturgical analysis of the service encounter in higher education. J. Mark. Manag. 2008, 24, 47-68. [CrossRef]

33. Nelson, K.B. Enhancing the attendee's experience through creative design of the event environment: Applying Goffman's Dramaturgical Perspective. J. Conv. Event Tour. 2009, 10, 120-133. [CrossRef]

34. Pan, M.-C.; Lee, T.-R.; Anbuudayasankar, S.P.; Ganesh, K. Key success factors of holding exhibitions for the exhibition organisers using dramaturgy model and grey relational analysis. Int. J. Tour. Policy 2014, 5, 269-295. [CrossRef]

35. de Lassus, C.; Freire, N.A. Access to the luxury brand myth in pop-up stores: A netnographic and semiotic analysis. J. Retail. Consum. Serv. 2014, 21, 61-68. [CrossRef]

36. Auh, S.; Bell, S.J.; McLeod, C.S.; Shih, E. Co-Production and Customer Loyalty in Financial Services. J. Retail. 2007, 83, 359-370. [CrossRef]

37. Cook, S. The Contribution Revolution: Letting Volunteers Build your Business. Harv. Bus. Rev. 2008, 86, 60-69.

38. Cova, B.; Dalli, D.; Zwick, D. Critical Perspectives on Consumers' Role as 'Producers': Broadening the Debate on Value Co-Creation in the Marketing Processes. Mark. Theory 2011, 11, 231-241. [CrossRef]

39. Zwass, V. Co-Creation: Toward Taxonomy and an Integrated Research Perspective. Int. J. Electron. Commer. 2010, 15, 11-48. [CrossRef]

40. Hills, M. Fan Cultures; Routledge: Abingdon, UK, 2002.

41. Jenkins, H. Fans, Bloggers, Gamers: Exploring Participatory Culture; New York University Press: New York, NY, USA, 2006.

42. Sandvoss, C. Fans: The Mirror of Consumption; Polity Press: Cambridge, UK, 2005.

43. Chaudhuri, A.; Holbrook, M.B. The chain of effects from brand trust and brand affect to brand performance: The role of brand loyalty. J. Mark. 2001, 65, 81-93. [CrossRef]

44. Sarkar, J.G.; Sarkar, A.; Ponnam, A. Exploration of brand sacralization among the young adult consumers in the context of emerging Asian market. Young Consum. 2015, 16, 264-280. [CrossRef]

45. Muniz, A.M., Jr.; Schau, H.J. Religiosity in the abandoned Apple Newton brand community. J. Consum. Res. 2005, 31, 737-747. [CrossRef]

46. Bitner, M.J. Servicescapes: The Impact of Physical Surroundings on Customers and Employees. J. Mark. 1992, 56, 57-71. [CrossRef]

47. Kotler, P. Atmospherics as a marketing tool. J. Retail. 1973, 49, 48-64.

48. Baker, J. The Role of the Environment in Marketing Services: The Consumer Perspective. In The Services Challenge: Integrating for Competitive Advantage; Czepiel, A.J., Congram, C.A., Eds.; American Marketing Association: Chicago, IL, USA, 1987 ; pp. 79-84.

49. Peter, J.P.; Olson, J.; Grunert, K. Consumer Behaviour and Marketing Strategy: European Edition; McGraw-Hill: New York, NY, USA, 1999.

50. Jang, Y.; Ro, H.; Kim, T.-H. Social Servicescape: The Impact of Social Factors on Restaurant Image and Behavioural Intentions. Int. J. Hosp. Tour. Adm. 2015, 16, 290-309. [CrossRef]

51. Lundberg, C.; Mossberg, L. Learning by sharing: Waiters' and bartenders' experiences of service encounters. J. Foodserv. 2008, 19, 44-52. [CrossRef]

52. Nickson, D.; Warhurst, C.; Dutton, E. The importance of attitude and appearance in the service encounter in retail and hospitality. Manag. Serv. Qual. 2005, 15, 195-208. [CrossRef]

53. Tombs, A.; McColl-Kennedy, J.R. Social-Servicescape Conceptual Model. Mark. Theory 2003, 3, 447-475. [CrossRef]

54. Strong, A.C.; Harris, L.C. The Drivers of Customer Orientation: An Exploration of Relational, Human Resource and Procedural Tactics. J. Strateg. Mark. 2004, 12, 183-204. [CrossRef]

55. Touchstone, E.E.; Koslow, S.; Shamdasanim, P.; D'Alessandro, S. The Linguistic Servicescape: Speaking their Language May Not Be Enough. J. Bus. Res. 2017, 72, 147-157. [CrossRef] 
56. Mattila, S.A.; Wirtz, J. Congruency of Scent and Music as a Driver of In-Store Evaluations and Behaviour. J. Retail. 2001, 77, 273-289. [CrossRef]

57. Morin, S.; Dubé, L.; Chebat, J.-C. The Role of Pleasant Music in Servicescapes: A Test of the Dual Model of Environmental Perception. J. Retail. 2007, 83, 115-130. [CrossRef]

58. Booms, H.B.; Bitner, M.-J. Marketing Services by Managing the Environment. Cornell Hotel Restaur. Adm. Q. 1982, 23, 35-39. [CrossRef]

59. Wan, Y.K.P. Exploratory Assessment of the Macao Casino Dealers' Job Perceptions. Int. J. Hosp. Manag. 2010, 29, 62-71. [CrossRef]

60. Kim, I.-K. Subjective Responses to Daylight, Sunlight, and View in College Classrooms with Windows. Ph.D. Thesis, Texas A \& M University, College Station, TX, USA, 1998.

61. Summers, A.T.; Hebert, P.R. Shedding Some Light on Store Atmospherics: Influence of Illumination on Consumer Behaviour. J. Bus. Res. 2001, 54, 145-150. [CrossRef]

62. Fitzsimmons, B. Restroom Cleanliness: The Last Detail. Restaur. Hosp. 2003, 87, 100-102.

63. Wakefield, L.K.; Blodgett, J.G. The Effect of the Servicescape on Customers' Behavioural Intentions in Leisure Service Settings. J. Serv. Mark. 1996, 10, 45-61. [CrossRef]

64. Aubert-Gamet, V. Twisting Servicescapes: Diversion of the Physical Environment in a Reappropriation Process. Int. J. Serv. Ind. Manag. 1997, 8, 26-41. [CrossRef]

65. Iyer, S.E. Unplanned Purchasing: Knowledge of Shopping Environment and Time Pressure. J. Retail. 1989, 65, 40-57.

66. Crowley, A. The Two-Dimensional Impact of Color on Shopping. Mark. Lett. 1993, 4, 59-69. [CrossRef]

67. Donovan, J.R.; Rossiter, J.R. Store Atmosphere: An Environmental Psychology Approach. J. Retail. 1982, 58, 34-57.

68. Ezeh, C.; Harris, L.C. Servicescape Research: A Review and a Research Agenda. Mark. Rev. 2007, 7, 59-78. [CrossRef]

69. Nguyen, N. The Collective Impact of Service Workers and Servicescape on the Corporate Image Formation. Int. J. Hosp. Manag. 2006, 25, 227-244. [CrossRef]

70. Han, H.; Ryu, K. The Roles of the Physical Environment, Price Perception, and Customer Satisfaction in Determining Customer Loyalty in the Restaurant Industry. J. Hosp. Tour. Res. 2009, 33, 487-510. [CrossRef]

71. Lam, W.; Long, K.W.C.; Fong, D.; Lo, F. Does the Look Matter? The Impact of Casino Servicescape on Gaming Customer Satisfaction, Intention to Revisit, and Desire to Stay. Int. J. Hosp. Manag. 2011, 30, 558-567. [CrossRef]

72. Arnould, J.E.; Price, L.L.; Tierney, P. Communicative Staging of the Wilderness Servicescape. Serv. Ind. J. 1998, 18, 90-115. [CrossRef]

73. Cohen, E. Authenticity and Commoditization in Tourism. Ann. Tour. Res. 1988, 15, 371-386. [CrossRef]

74. MacCannell, D. Staged authenticity: Arrangements of social space in tourist settings. Am. J. Sociol. 1973, 79, 589-603. [CrossRef]

75. Baudrillard, J. Simulacra and Simulations. In Selected Writings; Poster, M., Ed.; Stanford University Press: Palo Alto, CA, USA, 1988.

76. Quelch, J.A.; Klein, L.R. Opinion: The Internet and international marketing. Sloan Manag. Rev. 1996, 37, 60.

77. Karatepe, O.M.; Baddar, L. An Empirical Study of the Selected Consequences of Frontline Employees' Work-Family Conflict and Family-Work Conflict. Tour. Manag. 2006, 27, 1017-1028. [CrossRef]

78. Karatepe, O.M.; Uludag, O. Conflict, Exhaustion, and Motivation: A Study of Frontline Employees in Northern Cyprus Hotels. Hosp. Manag. 2007, 26, 645-665. [CrossRef]

79. Parish, J.T.; Berry, L.L.; Lam, S.Y. The Effect of the Servicescape on Service Workers. J. Serv. Res. 2008, 10, 220-238. [CrossRef]

80. Yoo, J.J.-E.; Shin, S.-Y.; Yang, I.-S. Key Attributes of Internal Service Recovery Strategies as Perceived by Frontline Food Service Employees. Hosp. Manag. 2006, 25, 496-509. [CrossRef]

81. Normann, R. Service Management: Strategy and Leadership in Service Business; Wiley: New York, NY, USA, 1984.

82. Corvellec, H.; Lindquist, H. (Eds.) Servicemötet-Multidisciplinära Öppningar; Liber: Malmö, Sweden, 2005.

83. Edvardsson, B.; Gustafsson, M.D.; Sandén, B.; Johnson, M.D. New Service Development and Innovation in the New Economy; Studentlitteratur: Lund, Sweden, 2000.

84. Wong, A.S.A.; Sohal, A. A critical incident approach to the examination of customer relationship management in a retail chain: An exploratory study. Qual. Mark. Res. Int. J. 2003, 6, 248-262. [CrossRef]

85. Hansen, D.E.; Danaher, P.J. Inconsistent Performance during the Service Encounter: What's a Good Start Worth? J. Serv. Res. 1999, 1, 227-235. [CrossRef]

86. Coye, R.W. Managing customer expectations in the service industry. Int. J. Serv. Ind. Manag. 2004, 15, 54-71. [CrossRef]

87. Keillor, B.D.; Hult, G.T.M.; Kandemir, D. A study of the service encounter in eight countries. J. Int. Mark. 2004, 12, 9-35. [CrossRef]

88. Lewis, B.R.; McCann, P. Service failure and recovery: Evidence from the hotel industry. Int. J. Contemp. Hosp. Manag. 2004, 16, 6-17. [CrossRef]

89. Parasuraman, A.; Zeithaml, V.A.; Berry, L.L. A conceptual model of service quality and its implication for future research. J. Mark. 1985, 49, 41-50. [CrossRef]

90. Bebko, C.P. Service Encounter Problems: Which Service Providers are More Likely to be Blamed? J. Serv. Mark. 2001, 15, 480-495. [CrossRef]

91. Bejou, D.; Edvardsson, B.; Rakowski, J.P. A Critical Incident Approach to Examining the Effects of Service Failures on Customer Relationships: The Case of Swedish and US Airlines. J. Travel Res. 1996, 35, 35-40. [CrossRef] 
92. Bejou, D.; Palmer, A. Service Failure and Loyalty: An Exploratory Empirical Study of Airline Customers. J. Serv. Mark. 1998, 12, 7-22. [CrossRef]

93. Halliday, S.V. How "Placed Trust" Works in a Service Encounter. J. Serv. Mark. 2004, 18, 45-59. [CrossRef]

94. Nielsen, J.F.; Host, V. The Path to Service Encounter Performance in Public and Private 'Bureaucracies'. Serv. Ind. J. 2000, 20, 40-60. [CrossRef]

95. Chandon, J.-L.; Leo, P.-Y.; Philippe, J. Service Encounter Dimensions-A Dyadic Perspective: Measuring the Dimensions of Service Encounters as Perceived by Customers and Personnel. Int. J. Serv. Ind. Manag. 1997, 8, 65-86. [CrossRef]

96. Pugh, S.D. Service with a Smile: Emotional Contagion in the Service Encounter. Acad. Manag. J. 2001, 44, 1018-1027. [CrossRef]

97. Lundberg, C.; Lexhagen, M.; Mattsson, S. Twication ${ }^{\mathrm{TM}}$ : The Twilight Saga Travel Experience; Jengel Förlag AB: Östersund, Sweden, 2012.

98. Burns, P. Hard-skills, soft-skills: Undervaluing hospitality's 'Service with a Smile'. Prog. Tour. Hosp. Res. 1997, 3, 239-248. [CrossRef]

99. Hochschild, A. The Managed Heart; University of California Press: Berkeley, CA, USA, 1983.

100. Hallier, J.; Butts, S. Employers' discovery of training: Self-development, employability and the rhetoric of partnership. Empl. Relat. 1999, 21, 80-95. [CrossRef]

101. Long, N.J.; Moore, H.L. Sociality revisited: Setting a new agenda. Camb. Anthropol. 2012, 30, 40-47. [CrossRef] 